\title{
Alliance of Ummah in Rural Areas: A New Perspective on Islamic Populism in Indonesia
}

\section{Rojabi Azharghany ${ }^{1 *}$, Hotman Siahaan ${ }^{2}$, Akh. Muzakki $^{3}$}

1 Airlangga University, Indonesia; e-mail: rojabi.azharghany-2018@fisip.unair.ac.id

2 Airlangga University, Indonesia; e-mail: hotman.siahaan@fisip.unair.ac.id

3 Sunan Ampel State Islamic University, Indonesia; e-mail: akh.muzakki@uinsby.ac.id

* Correspondence

Received: 2020-11-05; Accepted: 2020-12-14; Published: 2020-12-31.

\begin{abstract}
Islamic populism in Indonesia is perceived as an alliance of the people on behalf of the ummah in urban areas, against the ruling elites who enjoy the promises of peace and prosperity more than capitalism, modernism and democracy. This paper though intends to disclose the Islamic populism in rural areas through the power of capital and symbols as part of the suspension of differences between alliances in rural areas and large cities that simply focuses on political power. This research embraces the socio-cultural approach by applying the theory of generative structuralism penned by Pierre Bourdieu in order to analyze the resistance of suspension difference by invigorating the cultural reproduction and symbols dominance to thwart the ummah alliance in urban areas. The results of this research show that the Islamic populism in rural areas upholds the belief in salvation, peace and unity, by reinforcing the suspension differences among the congregations on various bases. In spite of domestication process in Islamic populism by the ruling elite, the ummah alliance in rural areas cannot be triggered due to their firm belief in salvation, which differs from the Islamic populism in large cities where a symbol of injustice of the bourgeoisie and the ruling elites prevails. The Islamic populism in rural areas has caused the failure of Islamic populism in large cities since their main discourse solely considers the middle class, in contrast to the Islamic populism in rural areas that might may welcome both the middle class and the lower class.
\end{abstract}

Keywords: Cultural Reproduction; Indonesia; Islamic Populism; Rural; Salvation.

Abstrak: Populisme Islam di Indonesia dilihat sebagai aliansi masyarakat mengatasnamakan umat di perkotaan, melawan elit penguasa yang dianggap lebih menikmati janji-janji kedamaian dan kesejahteraan dari kapitalisme, modernisme dan demokrasi. Sebaliknya, Tulisan ini hendak menunjukkan populisme Islam di pedesaan melalui kekuatan modal dan simbol-simbol yang menjadi bagian dari kekuatan penangguhan perbedaan (suspension of difference) aliansi umat ini sebagai pembanding terhadap aliansi umat di kota yang lebih fokus terhadap isi kekuasaan. Pendekatan yang digunakan dalam penelitian ini adalah sosial-budaya dengan menerapkan teori strukturalisme generatif Bourdieu untuk menganalisis ketahanan suspension of difference melalui reproduksi budaya dan dominasi simbol-simbol yang digunakan dalam berkontestasi dengan aliansi umat di perkotaan. Hasil dalam penilitian ini menunjukkan populisme Islam di desa bergerak melalui tradisi yang didasari "imaginasi keselamatan", kedamaian dan persatuan sebagai dasarnya, memiliki daya tahan dalam membangun suspension of difference di kalangan umat dengan basis yang beragam. Meskipun terdapat indikasi adanya proses domestikasi pada populisme Islam di Indonesia oleh elit penguasa, aliansi umat di pedesaan lebih cenderung tidak terpengaruh karena diskursus besarnya adalah keyakinan akan keselamatan, hal ini berbeda dengan populisme Islam di kota yang mengusung simbol ketidakadilan elit borjuis dan penguasa. Populisme Islam di desa juga menjadi penyebab gagalnya populisme Islam di kota karena diskursus yang digaungkan hanya menyentuh kelas menengah, berbeda dengan populisme Islam di desa yang dapat membaurkan kelas menengah dan bawah.

Kata Kunci: Indonesia; Keselamatan; Populisme Islam; Pedesaan; Reproduksi Budaya. 


\section{Introduction}

During the last decades, Indonesia has been under the spotlight of political scientists. They have specifically studied the alliance of ummah who are frequently present in major cities by raising the issue of upholding sharia to issues of justice and equality of people's welfare. There has not been any significant success of their resistance against the bourgeois elite, the rulers or other alliances outside the group that implicitly claims to be "moral".

Since the establishment of the Indonesian government, as proven by historical records, no single Islamic party has been able to seize a full control of the parliament regarding the issues of justice and equality. Up to now, only the nationalist parties take control of the government headed by the oligarchic forces behind it (Jeffrey A. Winters, 2013; Robison \& Hadiz, 2020; Zulham, 2020). As matter of fact, only two Islamic parties exist in the central parliament amongst the nine nationalist parties, namely the Partai Persatuan Pembanguan (PPP) and the Partai Keadilan Sejahtera (PKS) which have been further weakened by the entry of the PPP party in supporting the government. Similarly, myriads of factions occur within the Indonesian Muslim society which have been eradicated by the government such as the Darul Islam (DI) and Hizbut Tahrir Indonesia (HTI) as well as those that are still popular today, such as Nahdlatul Ulama (NU), Muhammadiyah and Front Pembela Islam (FPI).

On the other hand, there are ummah alliances in rural areas which embrace the symbols of belief in salvation through traditions. The salvation in question is a common belief shared within the people's alliance regarding their hope in achieving a better life in this world, to gain success and health, and to survive in the afterlife. They call themselves the people of the nahdliyin. The traditions they uphold have existed within their lives and become part of their hereditary heritage used as a habit which is thoroughly in conformity with their social laws. They call it the nahdliyin tradition or the amaliyah Nahdlatul Ulama (NU). The traditions they practice have actually transcended various ideologies and periods of world political economy. Starting from communist ideology, liberalism to Pancasila democracy; starting from the feudal period, colonial, imperialist, to the modernization of the free market. It is even said that the tradition practiced by the people of nahdliyin has been rooted deeply since the periodization of the songo guardians in the 15th century (Ricklefs, 2012). Thus, it is not surprising to see that this tradition which is equipped with special ritual has taken root and has been tested as a tradition that is part of the life of the nahdliyin people.

The forerunner of this ummah alliance in rural areas sprouted through pesantren and traditional associations in the community (jamiyah) in traditional forms such as tarekat, tahlilan, selametan, syarwa'an, manaqiban and sholawatan which were led by kiai and local traditional leaders. The continuation of this tradition in its development was the formal institution of NU. The researcher's assessment has assessed that the tradition that has lived with the people of Nahdliyin has become part of daily rites and the community's adaptation system (Van Bruinessen \& Wajidi, 2006), becoming a mindset in addressing the life of the nation and state (Fealy \& Bush, 2014; Feillard, 2013), and has formed a culture of consensus in shaping a moderate and tolerant Islamic civilization (Brown, 2019).

Nowadays, the ummah alliance in rural areas is showing its stretch by gathering large numbers of people through its jamiyah or majelis sholawat by carrying out ritual practices as practiced by the people of Nahdliyin. It can be ascertained that in all regional areas of Indonesia, especially in rural communities there is an alliance of ummah who carry this love of prayer. For example, in Probolinggo Regency, based on the narrative of the head of the PCNU da'wah Agency in Probolinggo district, Hafidz Hakiem Noer, roughly 48 prayer assemblies are reported, including tens of thousands of followers, namely Jamiyah Syubbanul Muslimin, Ahbabul Mustofa and Alwali.

The activities conducted by members encourages the love of sholawat which is viewed as the amaliah NU (Nahdlatul Ulama), such as reading the simtudduror, diba ', barzanji, and tahlil-which is respectively a collection of Arabic texts, made by Middle Eastern scholars, is read to praise the Prophet Muhammad and believed by the people's alliance as a mediator for salvation in this world and the hereafter. Other than carrying out the NU religious rituals, the implementation of a series of activities is filled with singing songs embracing the Indonesian love, like the national hymn known as the 'Indonesia Raya' and the Syubbanul Wathon (Indonesian youth). Besides, there are also lectures or 
religious speeches delivered by religious elites who they refer to as kiai or habib. The discourse presented in the lecture was about maintaining the NU traditions, loving the cleric, preserving the Unitary State of the Republic of Indonesia through an imaginary process of peace and salvation as voiced in religious doctrines, because unity is part of salvation considering that unity is peace in guaranteeing serenity while conducting worships.

The ummah alliance in rural areas is not just a mere "mass culture" (N. Johnson, 2019; Macdonald, 1953) that gathers only for a temporary goal on a mass basis that can easily split because its goals are only momentary and inconsistent. If observers see the ummah alliance in the cities, which is more viewed from their movements against political power, they call it Islamic populism, which makes it appropriate to consider that the alliance of ummah in rural areas is a variant of Islamic populism in Indonesia.

Populism can be defined as a multi-class alliance movement that is asymmetrical, consisting of various classes and social status, with certain social groups which hold a dominant role, while others follow. The impact is the suspense of difference. The discourse used in these alliances tends to benefit the leading class (Mudde \& Kaltwasser, 2017). Thus, the alliance of ummah in rural areas which have a diverse class base - although with a different goal from the alliance of ummah in major cities, which is to position themselves at peace with power but while maintaining the principles of tradition deserves to be examined based on the Islamic populism perspective.

This research is important since the Islamic populism, when considering the alliance of ummah in the rural areas, it is hardly spotlighted from the Islamic populism researchers, especially when it comes to socio-cultural approach. The existing research looks more at Islamic populism in large cities and uses a political-economy approach. Vedi Hadiz (2014), for example, highlights the Islamic populism with a political economy approach based in cities by comparing Indonesia, Egypt and Turkey. Its appearance is part of a disappointed response to the contradiction of the welfare promises of global capitalism. The growing ambition and frustration articulated by the urban middle class throughout the Muslim world, including in these three countries, is working with the urban poor population, the goal is to gain access to power and resources for the voiced of the oppressed.

Based on political economic point of view, the Islamic populism is also perceived as a resistance movement against the ruling elite. Its existence always makes a difference between the ummah as moral and the immoral ruling elite. Thus, the produced label created new conflicts. Conflict never ceases to develop around the world when there is an enlargement of the issue of a new type of social marginalization and disillusionment with liberal modernity for breaking the promises (Hadiz \& Chryssogelos, 2017).

Also, based on political power point of view, another factor that causes the emergence of Islamic populism is the crisis of trust in democratic representation portrayed by the ruling elite. The promise of justice from a democratic system is considered as a failure for it creates a lot of inequality (Amal, 2020). However, the latest development of a political approach about the Islamic populism in Indonesia finds that the Islamic populism movement is no longer intensive in voicing the reinforcement of a sharia state which views the democratic system as a failure, but has made peace with democracy in order to achieve a broader public support in hope to seize power and resources by conducting ummah based political identity (Hadiz, 2018).

Failures not only prevail within the sharia state but also in the Islamic populism in major cities which have been perceived as a failure in getting the attention of the lower class and the bourgeoisie in Indonesia resulting in the fact that there has never been any success in urban populism in seizing power and economic resources from the ruling oligarchy. Unlike the case in Turkey, Islamic populism is formed from three forces, namely the blend of the middle class, the lower class and the Islamic bourgeoisie (Hadiz, 2016). As a result, the Islamic populism in Turkey has been able to overcome the dominance of the nationalist-curricular power of the Kemalist regime, and even to this day it controls the Turkish Justice and Development Party (AKP) in hope to establish a project based on Islamic ideology cadres led by Recep Tayyip Erdogan (Yilmaz, 2018). 
As far as the Islamic populism in electoral politics in Indonesia is concerned, especially regarding the 2019 presidential and vice presidential elections, the failure of Islamic populism in large cities is demonstrated by three things: first, the support for the democratic process which is still quite strong; second, the Islamic populism used by Prabowo's group is not part of the mainstream Islam in Indonesia; and third, historically speaking, the Islamic populism has always been contested massively in Indonesian politics so that its influence in politics can always be debated (Hara \& Trihartono, 2019). Mainstream Islam in question is shown by other research represented by traditional moderate groups, namely the NU and Muhammadiyah. For instance, NU has a much larger base in rural areas. Mainstream Islam is even more inclined towards a democratic system and takes a position of peace with power and to distance itself from power without any frontal resistance (Adiwilaga, Mustofa, \& Rahman, 2019).

A thorough analysis has even been aimed at the Islamic populism in urban areas as a fragile Muslim alliance, because there is no single political facility in Indonesia that can effectively promote the aspirations of the ummah who are increasingly sociologically diverse. However, for the interests of the oligarchy, the Islamic populism still provides strong resources for political mobilization. Thus the Islamic populism is very important during the electoral contests only, which easily causes shifted factions of the oligarchy from one another. The result is that Islamists remain excluded from the dominant power structure even though they are increasingly visible in electoral politics and the attention they receive from researchers (Mudhoffir, 2020). Populism movements in many ways do not always represent a fundamental challenge to the status quo, they are even absorbed by the status quo. Thus, what happens in Indonesia is the reign of competition between oligarchs using the means of Islamic populism. Oligarchy is domesticating and absorbing the Islamic populism in Indonesia for long-term interests (Robison \& Hadiz, 2020).

With regard to the researches undertaken previously, it discloses that the conditions and failures of the Islamic populism in major cities, encourages the urgent switch of views to the movement of Islamic populism in rural areas, which Adiwilaga said in previous researches as the basis of mainstream Islam. Another assumption that makes it important to study the Islamic populism in rural areas is that the Muslim alliance is more established than urban populism. Moreover, the Islamic populism in rural areas has a competitive relationship with the urban populism in terms of discourse friction, issues and symbols that it carries. This last assumption is the possibility to see whether the failure of Islamic populism in urban areas is also due to the influence of challenges from Islamic populism in the rural areas.

Indeed, this research is very important for it uses a different approach compared to the previous ones though they as well studied populism. Nicos Mouzelis (1985) views populism as an institutional approach, namely an alliance that seeks to bypass the formal institution of politics which aims to directly bringing people closer to power. Ernesto Laclau (2005) chose the discourse approach stating that populism in relation to how the lower society is represented as a whole (populist) through processes related to language where differences are homogenized so that they become unified. The language process is a list of symbolic meanings of speeches from charismatic or demagogical leaders. More specifically, Islamic populism according to Vedi Hadiz (2016) based on the economic-political approach, clarifies the position of Islamic populism in a diametric way against the ruling and bourgeois elites who enjoy the fruits of globalization, modernization, capitalism, liberalism and democracy.

This research approach in Islamic populism though seizes the socio-cultural perspective to explain how social and traditional bases show the strength of the suspense of difference in rural community alliances whose aim is to focus on issues of unity and peace, instead of taking positions against power and issues of injustice such as urban Islamic populism. Thus, this research highlights not only the strength of the Islamic populism in the rural areas, but also provides a perspective that can complement the study of Islamic populism in Indonesia.

In order to explore how the power of Islamic populism in rural areas develops, this research uses the concept of cultural reproduction initiated by Pierre Bourdieu (1993), It has become a unitary concept to analyze how a culture becomes the dominant culture in society. This concept cannot be separated 
from Bourdieu's core concepts of habitus, capital and arena (P. Bourdieu, 1992). In general, this habitus provides the following characteristics: it shapes our world view, beliefs and values; our inclinations toward certain practices and values influenced by our trajectory culture; habitus is durable and mobile; habitus is arbitrary and not fully realized (Webb, Schirato, \& Danaher, 2002). The concept of habitus is used to trace the common sense that exists in the alliance of ummah in rural areas in the form of beliefs represented by language symbols in the form of "practical taxonomy" (Jenkins, 1992), and it includes a cultural tendency to convey certain things, a specific linguistic competence, and the social capacities to use that competence appropriately.

The concept of capital is the accumulation of labor that can be used for social adjustment ( $P$ Bourdieu, 1998). According to Bourdieu, capital as a structural basis is not limited to economic factors for there are other factors too, namely cultural, social and symbolic capital. Cultural capital is related to the objectification of culture; social capital is related to social connections; economic capital refers to the availability of material while the symbolic capital is in the form of social authority / legitimacy. Like habitus, capital is not an autonomous condition (P Bourdieu, 1986). The value of a capital is highly dependent on the habitus which is the objective structure of society. Not all capital can be recognized as a material form to gain or strengthen power. In comparison, when capital is in accordance with the habitus, it can be converted from one capital to another. For this reason, all capital is convertible, meaning that each capital can trigger the emergence of other capitals, so that it becomes a socially legitimate force (Mahar, Harker, \& Wilkes, 1990). This concept of capital will be used to trace the accumulation of capital that exists in this Muslim alliance.

The concept of arena will be later used as a perspective to observe the possibility of alliance elites who appear as the dominant symbol in producing and reproducing cultures with the ummah. The ummah alliances such as jamiah perceived from the perspective of Bourdieu (1995) are a space to maintain positions both by the alliance elites and the general public, especially when dealing with other alliances outside the group. The process of cultural reproduction in the arena in the form of an alliance of ummah will be explained more deeply through the Bourdieu's concept of inculcation and apropiation (Pierre Bourdieu \& Passeron, 1990) as a mechanism of socialization and legitimacy that goes hand in hand with perception and appreciation in the arena with a process that is continually repeated so that it becomes a common habitus. The process of inculcation and apropiation can provide an understanding that the habitus formed in social actors can occur through reciprocal mechanisms, namely structuring structures and structured structures.

The theoretical scheme of using Bourdieu's concept in this study can be seen in Figure 1.

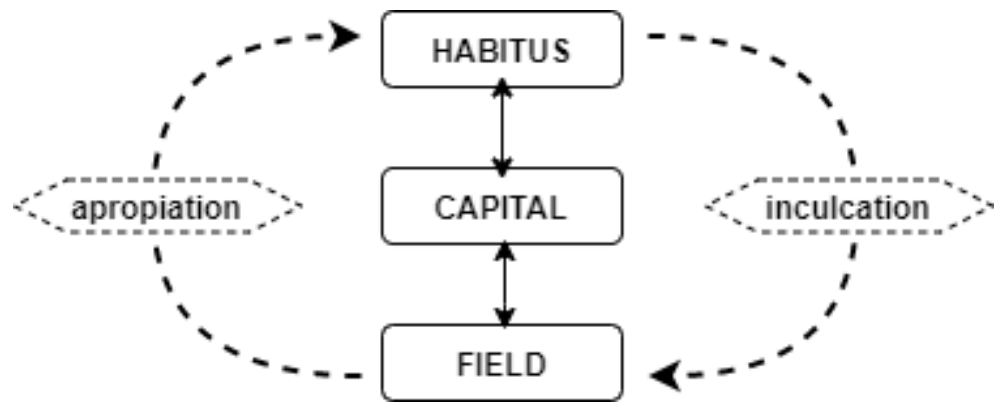

Figure 1 Conceptual schema of Islamic populism research in rural areas

As far as the approach and theory are concerned, this study uses a qualitative method. The process of collecting data through participant observation was conducted by digging deeper through interviews with the alliance leaders and ummah from the middle and lower class, totaling 7 people. The chosen ummah alliance is in the form of the Majelis Sholawat Syubbanul Muslimin, headquartered in Kalikajar Rural areas, Paiton District, Probolinggo Regency. The main reasons behind such choice include: first, the alliance was followed by people from various walks of life as the social basis; second, 
the alliance had an increasing followers of tens of thousands of people; third, the alliance grows from the rural community. The data analysis of this study was carried out in an interpretive-reflexive manner (P Bourdieu, 2003) through categorization, condensation, cross check and assessing various impressions (Alvesson \& Sköldberg, 2009).

\section{Experience of the Majelis Sholawat Syubbanul Muslimin}

"Blessed sholawat, immoral fleeing" is one of the taglines echoed by the assembly as observed on its attributes such as banners, flyers and books which record history since the inception of Syubbanul Muslimin in 2005 until now. This tagline was previously popularized by Habib Syech bin Abdul Qodir Asyegaf, founder of the Majelis Sholawat Ahbabul Mustofa in Solo. At the beginning of its formation, the assembly founded by Kiai Hafidzul Hakiem Noer who is known as Kiai Hafidz intentionally invited the youths who lived in Kalikajar Rural areas, Paiton District to make an association with the activity of praising the Prophet Muhammad or better known as sholawat or prayer.

Despite the initial goal of the association which was to target young people, as the jargon of the "millennial sholawat" it carries, elderly people are also enthusiastic to join. This could be due to the content of prayer performed by Kiai Hafidz accompanied by the Syubbanul Muslimin Group, containing pop qosidah-qosidah sholawat which are viral on Youtube in composing Islamic songs arranged by Indonesian pop songs or koplo. Kiai Hafidz though emphasizes the sholawat muktabaroh which is recognized among scholars, especially the nahdliyin scholars, such as Simtudduror, Dibaiyah, Barzanji and Burdah.

\section{The Sanad Alliance}

Developed within the community where one of its features is based on boarding school and nahdliyin residents, Sanad (the structure of the source of knowledge from teachers to the Prophet Muhammad) has become so important (Subekti, 2017). Sanad is believed by the community as a guarantee for the usefulness of knowledge and reading that is considered as sacred. The community knows the existence of Sanad from one's journey in learning, to whom the person studies (Naim, Personal Communication, June 7, 2020). This prayer council was recognized by Kiai Hafidz to read the prayers which continued to the Prophet Muhammad. Sanad was obtained by Kiai Hafidz while studying in Tarim, Yemen to Habib Salim Asyatiri whose scientific knowledge was continued to Habib Alawi Al Maliki and also continued to Habib Salim's father, Habib Abdullah Bin Umar to the author of the Sholawat Simtutduror, habib ali al habsyi to the Prophet Muhammad (Hafidz, Personal Communication, June 10, 2020).

\section{Guarding the Local Traditions and NU Traditions}

This prayer council develops by embracing the NU tradition and the local Javanese traditions which have been conducted from generation to generation by the rural communities in Probolinggo (Huda, 2018). Prayer has become a sacred tradition of the society in hope to obtain what they have expected in leading a convenient life in this world and in the hereafter. The hope of salvation is manifested in the prayers' recitation during rituals performed in pregnancy, childbirth, business opening, marriage, farming and rural areas preservation (Muawanah \& Hidayah, 2017). As a matter of fact, the Assembly simply followed the tradition that had long been rooted in society in large forms.

What we carry out in this assembly is simply hoping to continue the traditions that had been carried out by the community made by the scholars. I think in Indonesia this tradition has existed since the days of wali Songo (Hafidz, Personal Communication, June 15, 2020).

The tradition formulated in the activities of Syubbanul Muslimin was stated by Kiai Hafidz in order to fortify the community from the teachings of the group that divided the cleric and the Muslims by eliminating certain local traditions that were the legacy of previous scholars.

.... A group that often disbelieves Muslims and diverts the NU's amaliyah, usually aims to seize the political power (Hafidz, Personal Communication, June 20, 2020). 


\section{Fostering Moral and Love for the Motherland}

This assembly was also supported by other background due to the existence of hardship experienced by the rural areas who are considered by religious elites to perform immoral acts, such as drunkenness, drug use, theft, fights, adultery and affairs. The existence of this assembly has an attraction for youths in rural areas and the wider community to join and stop their immoral habits and embrace the hope of salvation by joining this assembly together. One of the interviewees on behalf of Aris (26) said:

I still remember back in 2011, when I was drunk riding a motorcycle. The next incident was, I hit the Syubban convoy on Alas Sumur road. Later, I found out from people that I immediately challenged them to a fight. But then the community secured them and brought home those who were injured hands and feet. The next day Kiai Hafidz and several other people visited me, gave me money and presented me with a koko shirt and wrapping cloth. At that time I felt embarrassed and the following days I was very curious to learn about the Syubban activities in hope to join them (Aris, Personal Communication, July 12, 2020).

Public sympathy for Syubbanul Muslimin is based on the moral teachings conducted in the assembly. Such moral teaching is in conformity with the Islamic religious law, local traditions and the spirit of preserving the unity of the Indonesian homeland.

Thus, we always remind the members to uphold the love of sholawat in hope to emulate the morals of Rosulullah, to get the syafaat Rosulullah so that we can embrace good morals........ As for the love of the country, apart from conveying it in our lecture, we also make it a part of every Syubban Muslimin event to sing the national hymn of 'Indonesia Raya and Syubbanul Wathon' (Hafidz, Personal Communication, June 22, 2020).

Pay attention to the word syafaat which means intercession. This statement is the key that by reading the prayer or the sholawat, one can get help (intercession) magically from the Prophet Muhammad to improve morals and peace for the Indonesian homeland.

\section{Diverse Social Bases}

At every event, the current followers of the Syubbanul Muslimin Assembly, as claimed by the Field Coordinator, Syakur, reach tens of thousands of worshipers dominated by the rural communities (as seen in figure 2). In addition, middle-class society such as teachers, lecturers, students, local elites, local businessmen and religious elites are also part of this assembly (Syakur, Personal Communication, June 30, 2020). They take part in the Syubbanul Muslimin activities while aiming to increase their love for the Prophet Muhammad as well as feeling the benefits of serenity in life. Hasan (38), who works as a lecturer, tells his story about how he joined the assembly:

There was a time when I had trouble in sleeping. Thinking too much makes my life restless. I don't

know how, but all of the sudden, I saw several pick-up cars carrying a group of people heading somewhere. I asked the people around them, and they said that there was a Syubban prayer event. It was already during night time, I was thinking to attend the event. During the event I felt something different. Even after the program, I still could feel the impact and when I arrived home around half past one in the morning, I tried to lie down on my bed. Thank you God, I can rest again. Until now. (Hasan, Personal Communication, July 13, 2020)

Besides, the assembly attracted bikers' communities such as CB motorcycle, Vespa motorbike, motor trail and bicycles to join the prayer sacred meeting. Sometimes they joined events held by other communities, but at other times, they held their own event together with Kiai Hafidz and the Syubbanul Muslimin group (Haq, 2019). 


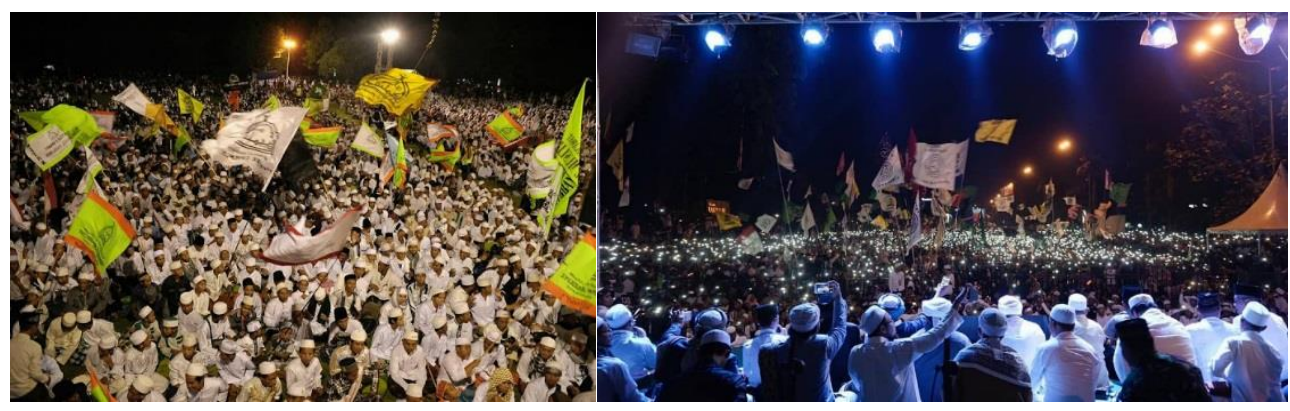

Figure 2 Ummah alliance in the Majelis Sholawat Syubbanul Muslimin

\section{Ummah Donation}

The funding source of the event usually comes from the host who organizes the event, and from other hosts who invite the Majelis Sholawat Syubbanul Muslimin outside the normal schedule. Hosts are usually people from the middle class society. One event may cost six to fifteen million, depending on how the host wants to set the event and the invited speakers (Syakur, Personal Communication, June 30, 2020).

Other sources of funding include: (1) the organization has a YouTube channel with an average income of 30 million rupiah per month; (2) tithes collected during the event provided to pick-up car drivers to transport the members; and (3) income from selling sacred water, merchandise, and Syubbanul Muslimin attributes managed by the Syubban Shop with a turnover reaching 200 million rupiah per year (Haq, 2019).

\section{The Capital Trajectory of Islamic Populism in Rural Areas}

The real strength of the alliance lies in their financial capital structural analysis (Mudde \& Kaltwasser, 2017). Bourdieu (1977) reminds that capital here cannot be merely associated with a set of material. Capital, for him, can be cultural, social, symbolic and economic. It is even revealed that cultural capital is the main force in producing and reproducing the habitus of social actors (P. Bourdieu, 1993). This section focuses on the trajectory of Islamic populism in rural areas which is meant to analyze its ability of suspense of difference through the experience of the Syubbanul Muslimin Assembly. The easiest way to undertake such step regarding the capital trajectories is that it will be divided into four categories based on Bourdieu's capital concept.

\section{Symbolic Power: Legitimate Text of Sholawat and Sanad}

Symbolic capital is thought to have the strongest influence as a source of dominant legitimacy (Mahar et al., 1990). The strong influence of the Sanad symbolization obtained by Kiai Hafid through his learning journey from a teacher known as the descendant of the Prophet Muhammad, can convince various social strata in acknowledging the blessings from the prayer recitation event that they embrace. The submission of the ummah is indicated by the symbolization of body movements when uttering prayers at certain passages. The symbolization is shown by pointing finger to the sky when calling the word "Allah" and raising one's hand to the sky when outpouring meaningful prayer asking for salvation (figure 3). Referring to the concept of symbolic power (Edelman, Bourdieu, Thompson, Raymond, \& Adamson, 1992), the facts that occur in Islamic populism in rural areas have been united by the dominance of the prayer passage, which is legitimized by Sanad, so that speech and movement can be carried out together no matter what their social bases are. 


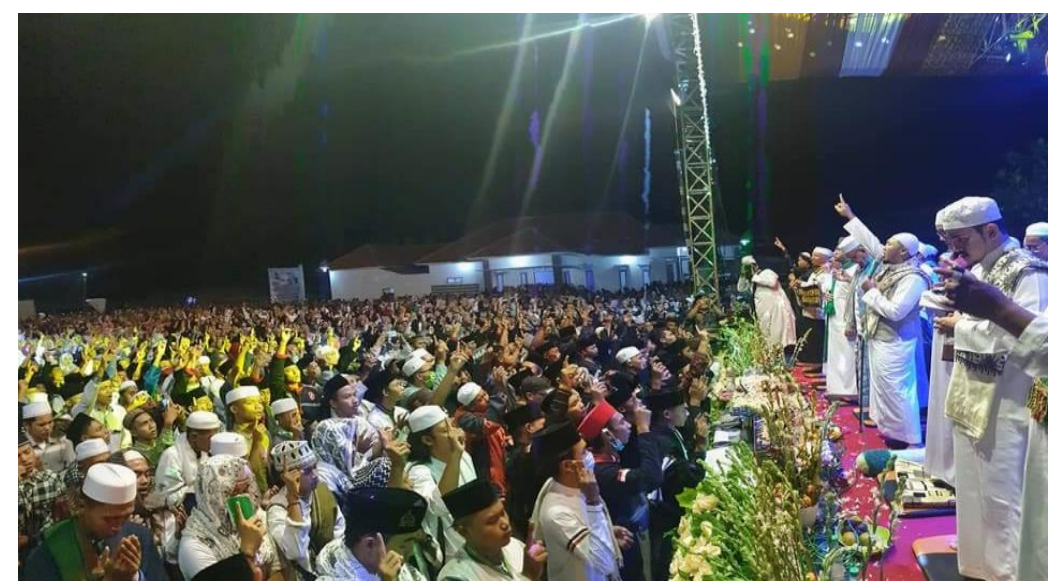

Figure 3 Symbol pointing to the sky led by religious elites

The use of internalized traditions in society

Traditional praying practices had existed for a long time, even before the spread of Islam in Indonesia (Fauzi, 2012). In Indonesia, prayer texts are met with traditional greetings which also have quite old historical roots (Muawanah \& Hidayah, 2017). Each tradition has a set of sublime meanings which are believed to lead to a good life as belief in the great traditions of the world (Zhoukuan, 2017). Islamic populism in countryside is based on traditions that had previously existed within the community and gathered in a bigger alliance. Thus, it is not hard for the Islamic populism in the rural areas to develop larger in quantity, since the activities that is carried out is part of the ummah habitus of life that is easily recognized, containing the meaning that they believe as a blessing.

\section{Uniting Diverse Social Bases}

What is populism? Hadiz (2016) explained this term according to social basis which represents one of the most important conditions in populism. More precisely, various social bases are united to reach a common goal. Bourdieu first saw that social capital network is seen as a power that appears as a manifestation of power over symbolic power and cultural power in society (P Bourdieu, 1986). This power is shown by Islamic populism in rural areas embedding diverse social bases from the middle class, which is supported by a large number of people from the lower classes. The various layers are united in the ummah alliance that carries a moral movement by highlighting the love of sholawat, as a universal language to be easily understood by all people.

\section{Economic Capital Conversion}

Islamic populism in the rural areas does not see economic factors as the most important condition above other capitals. The existence of economic capital is not a goal. It is only a tool in achieving common goals by converting them into support to strengthen the goals of the ummah alliance, such as transportation fees, accommodation needs, and event festivities. What can be ascertained is that all of the economic capital that was at stake in this community alliance would not return to the people in any material form, but in the form of enthusiasm for the realization of the hope of salvation after they have completed a series of rituals. Islamic populism in the rural areas seem to have understood Bourdieu's point that economic capital is most easily converted into other capital (P Bourdieu, 1986). So, they convert all sources of funding they get to fund the common goals.

\section{Reproducing the Imagination of Salvation}

The purpose of Islamic populism in rural areas is salvation. This goal is reproduced during the lesson after prayer which explains the importance of prayer in order to uphold intercession from the Prophet Muhammad so that he is saved in this world and in the afterlife; and this nation is safe for 
people to live peacefully while carrying out worships and live in harmony with each other. The dominant discourse is the "imagination of salvation" which colors and shapes the habitus of the ummah.

The imagination of salvation has become a universal language which is translated into various kinds of repeated information, stories, and doctrines. A kind of practical taxonomy is that by performing a prayer, listening to advice from religious elites, funding prayer activities, can lead to the salvation of oneself, family, community and nation. Bourdieu called this reproduction process as inculcation by emphasizing the euphemized language that is sacred, polite and worthy to be spoken and conveyed to the family and the public. In addition to the process of inculcation through euphemistic language, according to Bourdieu, there is also a process of inculcation through sensory (Pierre Bourdieu \& Passeron, 1990) which is manifested in body language by displaying exemplary models shown by religious elites. The appearance of being calm, focused (special), polite and understated during assembly activities is a sensory language that often appears.

This reproduction process does not stop at the action of instilling it to ummah. What can be found in the activities of Islamic populism in this rural area is the occurrence of appreciation, which is indicated by perception and appreciation (Pierre Bourdieu \& Passeron, 1990). Perception can be explained through the responses as a result of the involvement of social actors in this alliance to the imagination of salvation, as conveyed by Hasan in the sub-chapter of the experience of the Majelis Sholawat Syubbanul Muslimin. Hasan felt the serenity as a part of the salvation after joining the assembly. So, Hasan came to the assembly at another time with appreciation through the spoken and body language. The spoken language is expressed by reading the prayer texts together with other followers, led by the religious elite, while the body language mimics the body language demonstrated by the religious elite as well as other followers. Readings and movements that are carried out simultaneously in this community alliance, become a parade which signifies the reproduction of the habitus of salvation imagination that continues over and over again at every Syubbanul Muslimin event.

\section{Antagonism of Islamic Populism in Rural areas}

Laclau linked populism with antagonism. The thesis proposed that within populism, there is always antagonism which is the main characteristic of populism (Laclau, 2005). As explained in previous studies regarding populism in major cities, that is characterized by an alliance of ummah who always take positions against the ruling elite with the aim of accessing and gaining power because they are considered to have broken the promise of justice. It is clear that antagonism is the main sense of Islamic populism in big cities.

Supporting the research undertaken by Laclau, this study found the sense of antagonism which underlies the Islamic populism in rural areas; however, it is not the main striking feature of the Islamic populism movement in rural areas. According to the observations and information from the subject, this study sees that antagonism is only an inset material in the lectures and daily conversations of the people's alliance. The main part is to fortify the people by guarding the tradition from deviant beliefs.

It is better to be busy saving the community by guiding them to preserve the tradition of nahdliyin and spread the teachings of peace, than to spend time discussing those who have always failed to attack us with their heretics and provocative invitations that disintegrate the nation (Hafidz, Personal Communication, June 10, 2020).

Indirectly, the expressed language shows the existence of a cold war of Islamic populism in large cities and in rural areas. This side of antagonism causes populism in major cities to fail because it gains resistance from rural populism with a larger number of followers (NU) though it is not a face to face resistance. Undoubtedly, its style differs from the Islamic populism in urban areas as its opponents. The strategy conducted by the ummah alliance in rural areas is about survival since the values developed solely focus on moderation, adaptation and tolerance, which is consequently apathetic sometimes for the opponents or at any time to respond with satire style. 


\section{Conclusions}

The ummah alliance in rural areas is another type of Islamic populism that can unify various elements and social strata from middle to lower classes with the aim of spreading the words of salvation, peace and unity. It is very different from the Islamic populism in major cities which take a more opposing position and voices the injustice of other groups. The resilience of Islamic populism in rural areas is shown by the complexity of capital with the support of strong cultural capital, because it has been rooted for so long in the society as a habitus. The complexity of capital is continually reproduced into a social habitus in the form of "the imagination of salvation". The reproduction process by utilizing the universal language of religion for the imagination of salvation can be properly understood by the people, so that the impact is more stable in maintaining the suspense of difference between various social bases. The next important thing is, the stronghold of the tradition of Islamic populism in the rural areas is more effective compared to the antagonism of direct resistance in facing Islamic populism in cities, which indirectly causes the failure of Islamic populism in cities.

This research provides a complementary contribution to the study of the discourse on Islamic populism in Indonesia. It is hoped that the study of Islamic populism will not only be centered on an urban basis which tends to use a political-economy approach considering that the essence of populism is a suspense of difference of various mass bases. In addition, studies that tend to lead Islamic populism towards a frontal movement can create Islamic phobia, which has a negative impact on the discourse of peace in the life of the nation, state and society.

\section{Conflicts of Interest}

The author states no interest in taking sides with certain groups in describing, analyzing and providing conclusions regarding the study of Islamic populism in Indonesia. Hopes were merely conveyed to help contribute to the discourse of peace in Indonesia.

\section{References}

Adiwilaga, R., Mustofa, M. U., \& Rahman, M. R. T. (2019). Quo Vadis Islamic Populism? An Electoral Strategy. Central European Journal of International \& Security Studies, 13(4).

Alvesson, M., \& Sköldberg, K. (2009). Reflexive methodology-new vistas for qualitative research. https://doi.org/10.1080/13642531003746857

Amal, M. K. (2020). Explaining Islamic Populism in Southeast Asia: an Indonesian Muslim Intellectuals Perspective. Journal of Critical Reviews, 7(5), 583-588. https://doi.org/10.31838/jcr.07.05.121

Bourdieu, P. (1992). The logic of practice (R. Nice, ed.). Stanford: Stanford University Press.

Bourdieu, P. (1993). The Field of Cultural Production (R. Johnson, ed.). Columbia: Columbia University Press.

Bourdieu, P. (1986). The forms of capital. In J. G. Richardson (Ed.), Handbook of Theory and Research for the Sociology of Education (pp. 241-258). New York: Greenwood Press.

Bourdieu, P. (1995). Outline of a theory and practice. In Cambridge studies in social anthropology. Cambridge: Cambridge University Press.

Bourdieu, P. (1998). Practical reason: On the theory of action. Stanford: Stanford University Press.

Bourdieu, P. (2003). Participant Objectivation. Journal of the Royal Anthropological Institute, 9(2), $281-294$. https://doi.org/10.1111/1467-9655.00150

Bourdieu, Pierre. (1977). Outline of A Theory of Practice (R. Nice, trans.). Cambridge: Cambridge University Press.

Bourdieu, Pierre, \& Passeron, J.-C. (1990). Reproduction in education, society and culture. London: Sage.

Brown, G. (2019). Civic Islam: Muhammadiyah, NU and the Organisational Logic of Consensus-making in Indonesia. Asian Studies Review, 43(3), 397-414. https://doi.org/10.1080/10357823.2019.1626802

Edelman, M., Bourdieu, P., Thompson, J. B., Raymond, G., \& Adamson, M. (1992). Language and Symbolic Power. Contemporary Sociology, 21(5), 717. https://doi.org/10.2307/2075589

Fauzi, M. L. (2012). Traditional Islam in Javanese society: The roles of kyai and pesantren in preserving Islamic tradition and negotiating modernity. Journal of Indonesian Islam, 6(1), 125-144. https://doi.org/10.15642/JIIS.2012.6.1.125-144

Fealy, G., \& Bush, R. (2014). The Political Decline of Traditional Ulama in Indonesia. Asian Journal of Social Science, 42(5), 536-560. https://doi.org/10.1163/15685314-04205004

Feillard, A. (2013). Nahdlatul Ulama in Indonesia. In J. L. Esposito \& E. E.-D. Shahin (Eds.), The Oxford Handbook of 
Islam and Politics. New York: Oxford University Press.

Hadiz, V. R. (2014). A New Islamic Populism and the Contradictions of Development. Journal of Contemporary Asia, 44(1), 125-143. https://doi.org/10.1080/00472336.2013.832790

Hadiz, V. R. (2016). Islamic populism in Indonesia and the Middle East. Cambrige: Cambridge University Press.

Hadiz, V. R. (2018). Imagine All the People? Mobilising Islamic Populism for Right-Wing Politics in Indonesia. Journal of Contemporary Asia, 48(4), 566-583. https://doi.org/10.1080/00472336.2018.1433225

Hadiz, V. R., \& Chryssogelos, A. (2017). Populism in world politics: A comparative cross-regional perspective. International Political Science Review, 38(4), 399-411. https://doi.org/10.1177/0192512117693908

Haq, M. N. (2019). Syubbanul Muslimin: Menebar Dakwah dengan Cinta. Probolinggo: Majelis Syubbanul Muslimin Press.

Hara, A. E., \& Trihartono, A. (2019). The Failure of Islamic Populism: The Case of Indonesia's 2019 Election. Proceedings of the 1st Annual Internatioal Conference on Social Sciences and Humanities (AICOSH 2019). https://doi.org/10.2991/aicosh-19.2019.59

Huda, N. (2018). Mohammad in Archipelago: Spatializing Spirituality in Majelis Shalawat Syubbanul Muslimin in Kalikajar Probolinggo. Islamic Studies Journal for Social Transformation, 1(2), 114. https://doi.org/10.28918/isjoust.v1i2.1141

Jeffrey A. Winters. (2013). Oligarchy and Democracy in Indonesia. Indonesia, (96), 11-33. https://doi.org/10.5728/indonesia.96.0099

Jenkins, R. (1992). Key Sociologists Pierre Bourdieu. London: Routledge.

Johnson, N. (2019). Mass Culture and Islamic Populism. In G. Stauth \& S. Zubaida (Eds.), Mass Culture, Popular Culture, and Social Life in the Middle East. https://doi.org/10.4324/9780429035289

Laclau, E. (2005). On populist reason. London: Verso.

Macdonald, D. (1953). A Theory of Mass Culture. Diogenes, 1(3), 1-17. https://doi.org/10.1177/039219215300100301

Mahar, C., Harker, R., \& Wilkes, C. (1990). The basic theoretical position. In An introduction to the work of Pierre Bourdieu (pp. 1-25). London: Springer.

Mouzelis, N. (1985). On the concept of populism: populist and clientelist modes of incorporation in semiperipheral polities. Politics \& Society, 14(3), 329-348.

Muawanah, E., \& Hidayah, R. (2017). The Intelectual Roots of "Islam Nusantara": Its Core Strength, Relevance and Contextualization. Istiqro, 15(02), 517-546.

Mudde, C., \& Kaltwasser, C. R. (2017). Populism: A very short introduction. New York: Oxford University Press.

Mudhoffir, A. M. (2020). Islamic Populism and Indonesia's Illiberal Democracy. In Democracy in Indonesia: From Stagnation to Regression? Singapore: ISEAS Publishing.

Ricklefs, M. C. (2012). Islamisation and its opponents in Java: A political, social, cultural and religious history, c. 1930 to the present. Singapore: NUS Press.

Robison, R., \& Hadiz, V. R. (2020). Populism in Southeast Asia: A Vehicle for Reform or a Tool for Despots? In T. Carroll, S. Hameiri, \& L. Jones (Eds.), The Political Economy of Southeast Asia (pp. 155-175). https://doi.org/10.1007/978-3-030-28255-4_6

Subekti, A. (2017). Ekspansi Kompeni Hingga Sanad Kiai-Santri: Sejarah Islamisasi Ujung Timur Pulau Jawa Abad XVII-XX. Shahih: Journal of Islamicate Multidisciplinary, 2(1), 1-20. https://doi.org/10.22515/shahih.v2i1.686

Van Bruinessen, M. M., \& Wajidi, F. (2006). Syu'un ijtima'iyah and the kiai rakyat: Traditionalist Islam, civil society and social concerns. In H. S. Nordholt \& I. Hoogenboom (Eds.), IndonesianTransitions. Yogyakarta: Pustaka Pelajar.

Webb, J., Schirato, T., \& Danaher, G. (2002). Understanding bourdieu. London: Sage.

Yilmaz, I. (2018). Islamic Populism and Creating Desirable Citizens in Erdogan's New Turkey. Mediterranean Quarterly, 29(4), 52-76.

Zhoukuan, Z. (2017). The Approach of Great Tradition to Origin of Investigating-Things Theory. Journal of Baise University, 1(1).

Zulham, A. F. (2020). Political Strategy of Joko Widodo in Overcoming Oligarchy Politics in Indonesia. In Y. W. Santoso, F. S. Azzahra, \& Em. N. Toreh (Eds.), Indonesia's Path Toward Middlepowership. Surabaya: Airlangga University Press.

(C) 2020 by the authors. Submitted for possible open access publication under the terms and conditions of the Creative Commons Attribution (CC BY SA) license (https://creativecommons.org/licenses/by-sa/3.0/). 